\title{
Conservative management of placenta percreta
}

\author{
Yogita Gavit*, Deepika Sharma
}

Department of Obstetrics and Gynaecology, Government of Medical College, Aurangabad, Maharashtra, India

Received: 15 September 2020

Accepted: 02 November 2020

\section{*Correspondence:}

Dr. Yogita Gavit,

E-mail: dryogita1990@gmail.com

Copyright: (c) the author(s), publisher and licensee Medip Academy. This is an open-access article distributed under the terms of the Creative Commons Attribution Non-Commercial License, which permits unrestricted non-commercial use, distribution, and reproduction in any medium, provided the original work is properly cited.

\begin{abstract}
The incidence of placenta accreta, increta, percreta, collectively called placenta accrete spectrum disorders, has been rising dramatically over the last decade worldwide, mainly due to rising cesarean delivery rate. Antenatal diagnosis and making no attempt to remove any parts of placenta is associated with reduced levels of hemorrhage and therefore less blood transfusion. Although elective cesarean hysterectomy is the standard practice, the choice of conservative management has emerged into practice. Conservation of the uterus reduces numerous short- and long-term complications including massive blood transfusion, disseminated intravascular coagulopathy, high morbidity and mortality rates, adjacent pelvic organ damage, infection as well as long term psychological sequelae, due to loss of femininity and fertility. Hereby representing a model for the follow up of conservative management of placenta percreta. Sequential changes in symphysial fundal height, serum beta-HCG and ultrasonographic volume of the placenta mass were used as combined methods for the follow up of the case. The placental volume was calculated by using a 2-dimensional ultrasound scan by measuring the maximum length and anteroposterior and transverse diameters of the uterus and using the formula for the volume of prolate ellipsoid.
\end{abstract}

Keywords: Placenta percreta, Conservative management

\section{INTRODUCTION}

The placenta percreta is an abnormal penetration of chorionic villi in the myometrium and uterine serosa or adjacent organs. The incidence of placenta accreta has increased. Although the overall incidence of placenta percreta is low $(5 \%)$ the appearance of this rare disorder seems to be increasing due to performance of more cesarean deliveries because of their more extensive invasion through the uterus and into surrounding tissue, percretas are associated with higher incidence of morbidity and mortality (7\%). ${ }^{1}$ Antenatal diagnosis is mainly based on ultrasound and magnetic resonance imaging (MRI) technique. Currently well-defined organization of multidisciplinary therapeutic management is considered. ${ }^{2}$ Cases of placenta accrete managed without hysterectomy have recently been reported..$^{3,4}$

In order to persevere fertility, it was proposed to leave adherent placenta in situ at time of cesarean section. The purpose of our study was to report the experience of our department in the conservative management of placenta percreta.

\section{CASE REPORT}

Mrs. XYZ gravida 2 para 1 living 1 (G2P1L1) with 35 weeks of gestation with previous one lower segment cesarean section (LSCS) was diagnosed with placenta percreta at 32 weeks of gestation. Two-dimensional grayscale ultrasound showed features of morbid adherence (loss of cleat zone, presence of abnormal placental lacunae, bladder wall interruption and myometrium thinning). 2D color doppler revealed uterovesical hypervascularity and bridging and possible bladder wall involvement findings was confirmed by doing MRI 1.5 Tesla which reported placenta percreta (protrusion of placental tissue beyond the outer confines of uterine myometrium, increased vascularity between serosa and bladder). After complete blood investigation which was with normal limits and explaining approach of 
management and its risk informed consent taken, patient underwent elective classical cesarean section under epidural anesthesia. Intra-operative findings: uterovesical hypervascularity, bridging vessel and posterior bladder wall involvement.
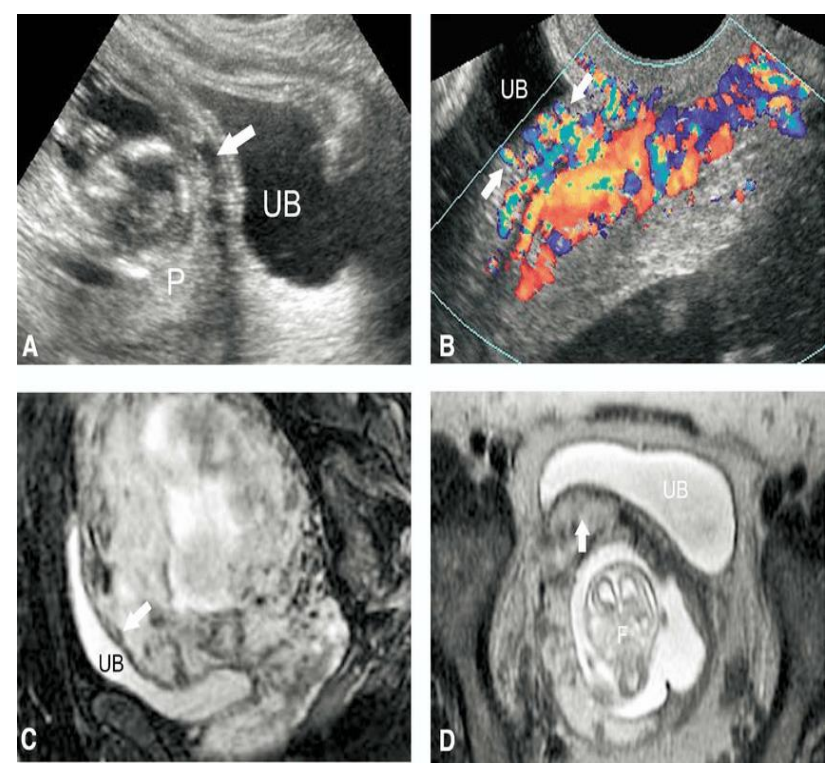

Figure 1: (A) ultrasound grayscale image thin tissue rim (arrow) between placenta $(P)$ and the urinary bladder (UB), representing previous $\mathrm{C}$-section scar

(B) colour doppler image presents placental flow immediately next to UB lumen (C) MRI depicts placental tissue invades UB (D) MRI depicts $P$ bulging anterior inferiorly against UB structure with only thin rim interposed tissue.

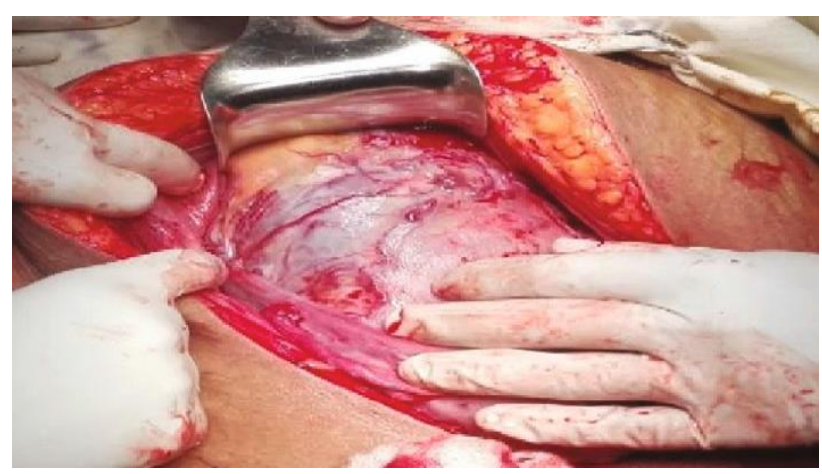

Figure 2: Intra-operative placenta percreta.

Baby delivered by vertex presentation cried immediately after birth weighing 2900 grams, maternal end umbilical cord tie, placenta was kept in situ uterine incision sutured with vicryl no 1, intra-operatively 2-pint pack cell volume; 4-pint Fresh Frozen Plasma; 2-pint platelet transfused, evidence of $600 \mathrm{ml}$ blood loss. Prohalactically right side internal iliac artery ligation done, left side was not accessible and homeostasis was achieved at systolic blood pressure $110 \mathrm{mmhg}$ (millimeter of mercury) abdomen was closed.

Intra-operative uneventful. Patient shifted to intensive care unit started injection piperacillin 4.45 gm 12 hourly, injection metronidazole $400 \mathrm{mg} 12$ hourly, antiemetics for 3 days followed with oral antibiotics for 5 days and conservative treatment with injection methotrexate 1 $\mathrm{mg} / \mathrm{kg}$ administered post-delivery given weekly for 4 weeks along with alternate day injection lecouvorin 0.1 $\mathrm{mg} / \mathrm{kg}$ day weekly for 4 weeks and patient was monitored with blood investigation, symphsial fundal height, placental volume every 14 days till it subsided.

Table 1: Investigation chart.

\begin{tabular}{|lllllll|}
\hline Day & $\begin{array}{l}\text { Pre- } \\
\text { operative }\end{array}$ & $\begin{array}{l}\text { Post-operative } \\
\text { day 2 }\end{array}$ & $\begin{array}{l}\text { Post-operative } \\
\text { day 6 }\end{array}$ & $\begin{array}{l}\text { Post-operative } \\
\text { day 12 }\end{array}$ & $\begin{array}{l}\text { Post- } \\
\text { operative } \\
\text { day 26 }\end{array}$ & $\begin{array}{l}\text { Post- } \\
\text { operative } \\
\text { day 54 }\end{array}$ \\
\hline Hb gm \% & 9.9 & 8.7 & 9.0 & 9.2 & 9.7 & 10 \\
\hline WBC cmm & 8000 & 10000 & 75000 & 7000 & 5800 & 5200 \\
\hline Platelet cmm & 2450000 & 2380000 & 2320000 & 2300000 & 2400000 & 2460000 \\
\hline Total Bilirubin & 0.5 & 0.5 & 0.6 & 0.5 & 0.6 & 0.6 \\
\hline SGPT/SGOT & $28 / 27$ & $28 / 25$ & $22 / 26$ & $25 / 27$ & $22 / 26$ & $20 / 22$ \\
\hline BUN & 10 & 9 & 10 & 12 & 10 & 10 \\
\hline Creatinine & 0.8 & 0.8 & 0.8 & 0.7 & 0.7 & 0.77 \\
\hline PT/INR & $16 / 1.0$ & $16 / 1.2$ & $16 / 1.1$ & $15 / 1.0$ & $15 / 1.0$ & $15 / 0.9$ \\
\hline
\end{tabular}

Hb- hemoglobin, WBC-white blood cell count, cmm- cubic millimeter, SGPT-serum glutamic-pyruvic transaminase, SGOT-serum glutamic-oxaloacetic transminase, BUN- blood urea nitrogen, PT/INR-prothrombin time /India normalized ration.

Table 2: Sequential changes in the clinical, bio-chemical, radiographical parameters.

\begin{tabular}{|llll|}
\hline Day & Symphsial fundal height $(\mathbf{c m})$ & Serum beta HCG(IU/ml) & Placental volume (ml) \\
\hline Pre-operatively & 34 & & \\
\hline Post-op day 6 & 25 & 26679 & 1450 \\
\hline Post-op day 12 & 24 & 8900 & 1073 \\
\hline Post-op day 26 & 24 & 1256 & 1030 \\
\hline
\end{tabular}




\begin{tabular}{|llll|}
\hline Day & Symphsial fundal height $(\mathrm{cm})$ & Serum beta HCG(IU/ml) & Placental volume (ml) \\
\hline Post-op day 40 & 20 & 211 & 703 \\
\hline Post-op day 54 & 17 & 19.5 & 490 \\
\hline Post-op day 68 & 11 & Less than 1.2 & 248 \\
\hline Post-op day 72 & Not palpable & Not detectable & 55 \\
\hline Post-op day 96 & Not palpable & Not detectable & - \\
\hline
\end{tabular}

Op- operative, cm-centimeter, IU/ml-International unit/milliliter ml-milliliter

\section{DISCUSSION}

There are three varieties of placenta accreta: placenta accrete in which there is no dividing line between the deciduas compacta and deciduas spongiosa, nor can operator establish any line of cleveage between the placenta and uterine wall; placenta increta in which the chorionic villi make contact with, but not invade the myometrium; placenta percreta in which the whole thickness of the myometrium is invaded to serosal surface with the possibility of rupture into peritoneal cavity. Known risk factors are manual removal of placenta at a previous birth, vigorous and repeated curettage, presence of submucous fibroid, placenta praevia, pregnancy in uterine diverticulum, previous cesarean section scar.

Maternal and perinatal morbidity is common in pregnancies with placenta percreta due to uterine rupture, blood loss, and ureteral ligation in pregnancies, fistula formation or infection. The option for treatment includes surgical removal of the uterus or conservative treatment with the placenta left in situ. In literature seven cases have been reported of conservative management of placenta percreta or placenta accrete with methotrexate5. We decided to start treatment with methotrexate due placenta deeply penetrating into bladder (muscularis wall) which was inaccessible to operate. It is suggested that Methotrexate acts not only on the dividing trophoblast cells but has effects on nevovascularization and growth factors as well. ${ }^{6}$ Methotrexate has been shown to decrease trophoblast activity and to reduce placenta vascularity. ${ }^{7}$ After treatment with methotrexate, the placental size, serum beta HCG, symphsial fundal size was assess every 14 days, reduced significantly after four courses. Our case demonstrates that conservative treatment for placenta percreta can be successful. By leaving a placenta accreta in situ after the delivery of the fetus, one can expect a progressive decrease in blood supply within the uterus, parametrium, and the placenta. This will result in secondary necrosis of the villous tissue, and thus the placenta should progressively detach itself from the uterus (and from the adjacent pelvic organs), finally to resorb or be expelled without significant complications. A large multicenter study in France with 167 cases of PAS disorders found an overall success rate of uterine preservation to be $78 \%$ in expectant approach, while the placenta resorbed spontaneously in $75 \%$ of cases (median: 13.5 weeks). ${ }^{8}$

The aim of the follow-up of these patients is to identify the women at risk for complications like delayed hemorrhages, endomyometritis, sepsis, uterocutaneous fistula9for early intervention and to decrease the morbidity rate. We used fundal height, placental volume, and serum beta-HCG in the follow-up. Placental volume measured in ultrasound scan became $50-52 \mathrm{ml}$ after 120 days in our case. Most reviews and guidelines recommended ultrasonographic follow-up for patients undergoing conservative management. ${ }^{10,11}$ Roulot et al reported in their case series that the appearance of an anechoic range on the remaining placental tissue could announce close elimination of the placenta. Furthermore, they found that the cessation of vascularization of the placental site took on average 47 days, corresponding clinically to the arrest of irregular vaginal bleeding described by the patients. ${ }^{12}$ Measurement of the pulsatility index (PI) of the uterine arteries is a noninvasive method that has been proposed for 4 case reports in obstetrics and gynecology use in the follow-up of conservative management of placenta accreta. ${ }^{13}$ With placental resorption, the low resistance flow of the placental bed disappears, resulting in an increase in PI of uterine arteries. The rising PI is associated with effective conservative management. ${ }^{13,14}$

\section{CONCLUSION}

The lifesaving modality of management is the early diagnosis of this condition. A multi-level disciplinary approach is the line of management. An increase number of cesarean sections and uterine curettages have increased the rate of abnormal placentation hence it is necessary to optimize the protocols required for management of these procedures. Conservative treatment may be alternative procedure in some selected cases of placenta percreta, patients and expertise must be warned about the risk of secondary complications these risks must reserve this management to centers with experience. Peripartum hysterectomy is the definitive management for placenta accrete disorders terminates woman's reproductive capacity though it is a lifesaving prodcure.

\section{Funding: No funding sources \\ Conflict of interest: None declared \\ Ethical approval: Not required}

\section{REFERENCES}

1. Committee on Obstetrics Practice, "ACOG committee opinion Placenta accrete Number 266, Januray 2002. America College of Obstetrics \& Gynecologists. Int J Gynecol Obstet. 2002;1:77-8. 
2. Tikkanen M, Paavonen J, Loukovaara M, Stefanovic V. Antenatal diagnosis of placenta accreta leads to reduced blood loss. Acta obstetricia et gynecologica Scandinavica. 2011;90(10):1140-6.

3. Hunt JC. Conservative management of placenta accreta in a multiparous woman. J Preg. 20100;2010.

4. Ghosh M, Chandraharan E. Management of postpartum haemorrhage. Obstet Gynaecol Reproduct Medic. 2017;27(8):239-44.

5. Gupta D, Sinha R. management of placenta accrete with oral Methotrexate. Int J Gynaecol Obstet. 1998; 60:171-3.

6. Kirkinen P, Dudenhausen J, Baumann H, Huch R. Postpartum blood flow velocity waveforms of the uetrine arteries . J Reprod Med. 1998;33:745-8.

7. Flam F, Kalstrom FP-OP, Carlsson B, Saroff L. Methotrexate for retained placental tissue. Eur Obstet Gynecol Reprod Biol. 1999;83:127-9.

8. Fox KA, Shamshirsaz AA, Carusi D, Secord AA, Lee P, Turan OM, et al. Conservative management of morbidly adherent placenta: expert review. Am J Obstet Gynecol. 2015;213(6):755-60.

9. Clausen C, Lönn L, Langhoff-Roos J. Management of placenta percreta: a review of published cases. Acta obstetricia et gynecologica Scandinavica. 2014;93(2):138-43.

10. Hayes E, Ayida G, Crocker A. The morbidly adherent placenta: diagnosis and management options. Cur Opin Obstet Gynecol. 2011;23(6):44853.

11. Royal College of Obstetricians and Gynaecologists, "Green-top Guideline No. 27. Placenta praevia, placenta praevia accreta and vasa praevia: diagnosis and management," RCOG, London, 2011.

12. Roulot A, Barranger E, Morel O, Soyer P, Héquet D. Apport de l'échographique 2D/3D dans le suivi de l'élimination du résidu placentaire après traitement conservateur de placenta accreta. J Obstet Gynecol Biol Reproduct. 2015;44(2):176-83.

13. Matsumura N, Inoue T, Fukuoka M, Sagawa N, Fujii $\mathrm{S}$. Changes in the serum levels of human chorionic gonadotropin and the pulsatility index of uterine arteries during conservative management of retained adherent placenta. J Obstet Gynaecol Res. 2000;26(2):81-7.

14. Jain A, Sepulveda W, Paterson-Brown S. Conservative management of major placenta previa accreta: three case reports. J Obstet Gynaecol. 2004;24(1):S63.

Cite this article as: Gavit Y, Sharma D.

Conservative management of placenta percreta. Int J Reprod Contracept Obstet Gynecol 2020;9:5140-3. 